\title{
Papilloma of the Tongue: About a Clinical Case at the Center Hospitalier Universitaire CHU Gabriel Toure in Bamako
}

\author{
Doumbia-Singare Kadidatou*, Sangaré Mariam, Kone Fatogoma Issa, Guindo Boubacary, \\ Soumaoro Siaka, Cisse Naoma, Konate N’Faly, Diarra Kassim, Timbo Samba Karim, \\ Keita Mohamed, Alhousseini AG Mohamed
}

Department of ENT and Head and Neck Surgery, Bamako, Mali

Email: *kadidia22000@yahoo.fr

How to cite this paper: Kadidatou, D.-S., Mariam, S., Issa, K.F., Boubacary, G., Siaka, S., Naoma, C., N’Faly, K., Kassim, D., Karim, T.S., Mohamed, K. and AG Mohamed, A. (2021) Papilloma of the Tongue: About a Clinical Case at the Center Hospitalier Universitaire CHU Gabriel Toure in Bamako. International Journal of Otolaryngology and Head \& Neck Surgery, 10, 1-5.

https://doi.org/10.4236/ijohns.2021.101001

Received: January 27, 2020

Accepted: December 7, 2020

Published: December 10, 2020

Copyright $\odot 2021$ by author(s) and Scientific Research Publishing Inc. This work is licensed under the Creative Commons Attribution International License (CC BY 4.0).

http://creativecommons.org/licenses/by/4.0/

\section{(c) (i) Open Access}

\begin{abstract}
Introduction: Tongue papillomas are benign epithelial tumors of the tongue lining. It is a precancerous lesion of viral origin caused by the Human papilloma virus (HPV). Objective: To describe the clinical and histological manifestations of a particular type of oral papilloma. Observation: A young woman aged 28 years resident in Siguiri (Guinea), received in consultation for a painless mass on the tongue slow evolving for 6 months duration. There was no notion of mouth bleeding. She had no particular medical and surgical history and negative for retroviral test/HIV test. Examination of the oral cavity found a fungating mass in at Right or Left posterior third of the tongue, painful on contact, sessile and pedunculated and not bleeding on contact and of soft consistency. The excision of the tongue mass was performed under general anesthesia. Biopsy was taken and sent for HPE. The consequences were mild, allowing her to be released 3 days after surgery. Histological examination showed an acanthotic stratified para-keratinized squamous epithelium containing small parts of connective tissue and koilocytes containing connective tissue nuclei reminiscent of papilloma. There was no malignancy cell. Conclusion: The papilloma of the tongue is a benign proliferative lesion characterized by slow and painless growth. I would say early diagnosis and surgical excision should be done to avoid recurrence, contact bleeding and morbidity secondary to mass effect.
\end{abstract}

\section{Keywords}

Papilloma, Tongue, Histology, Excision, HPV 


\section{Introduction}

Tongue papillomas are benign epithelial tumors of the tongue lining. It is a precancerous lesion of viral origin caused by the Human papilloma virus HPV. The prevalence of papillomavirus infections in this anatomical area has increased sharply in recent years [1].

Human papillomavirus (HPV) infection is recognized as one of the most common sexually transmitted infections [2]. The association of the human papillomavirus with cervical cancer has also been recognized for several years and more recently, its association with other types of cancer has also been observed, especially in the ENT (Otolaryngology) sphere [3]. It constitutes a major diagnostic and therapeutic problem. Clinically, papillomas look like other benign papillary epithelial tumors like common warts and genital warts.

Oral papillomatosis occurs at any age with a higher frequency in the thirties and is mainly observed on the palatal, lingual, labial and gingival mucosa in decreasing order of importance [4].

Surgical removal is the treatment of choice by routine excision or laser ablation [3] [4].

We describe the clinical and histological manifestations of a particular type of oral papilloma in a young woman.

\section{Observation}

It was a young woman aged 28 years resident in Siguiri (Guinea), housewife, married for 9 years, heterosexual, received in consultation on 15/O2/2018 for a painless masse on the anterior third of the back of the tongue.

We propose to describe the clinical and histological manifestations of a particular type of oral papilloma in a young woman.

The history of the disease goes back to about six months marked by the progressive installation of a painless, non-bleeding swollen tongue evolving on a permanent background associated with a swelling of the left lower eyelid, emaciation, non fever quantified, diarrhea, and anorexia. In front of this table, she performed several medical treatments such as unspecified tablet and mouthwash without success. Faced with the increase in the number and volume of the swelling, she consults us for better treatment. She had no particular medical or surgical history.

She had two pregnancies with two parities with a living child, and a deceased child.

Regarding her lifestyle, she started sex at the age of 15 with a notion of three sexual partners before marriage and frequent oral sex.

Oral examination found a mass in cauliflower (bunch of grapes) developed on the anterior third of the back of the tongue, painful not bleeding on contact, sessile and of soft consistency (Figure 1).

The examination of the cervico-facial skin found a swelling in the level of the lower left eyelid of furunculated appearance aspect. 
The general examination found a temperature at $37.8^{\circ} \mathrm{C}$, a weight at $48 \mathrm{kgs}$; a height of $160 \mathrm{~cm}$ with a body mass index (BMI) of 18.75 .

The gyneco-obstetric examination did not find a condyloma in the genital area.

HIV serology test came back as type 1 positive with a CD4 count of $244 \mathrm{ml}$.

The excision of the lesion was performed under general anesthesia with orotracheal intubation. The consequences were simple, allowing it to be discharged 3 days postoperatively (Figure 2).

Histopatological examination (HPE) of the mass showed an acanthotic stratified para-keratinized squamous epithelium containing small parts of connective tissue and koilocytes containing connective tissue nuclei evoking papilloma (Figure 3).

We did not notice a recurrence after a follow-up at 6 months and 9 months.

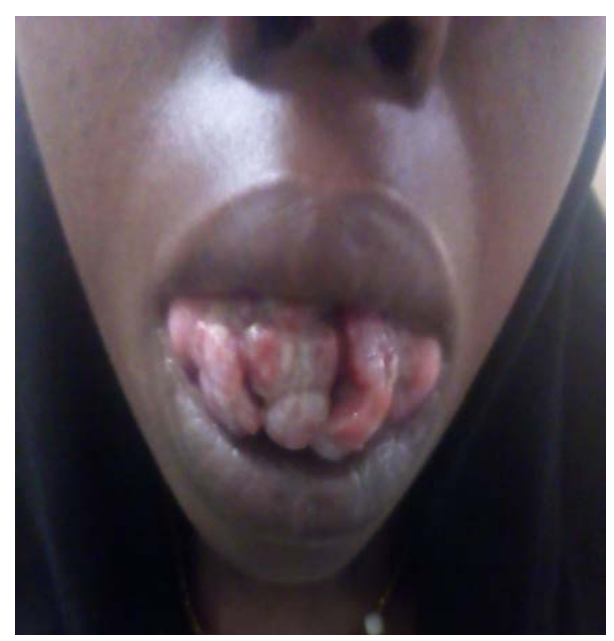

Figure 1. Whitish lesion in cauliflower on the back of the tongue.

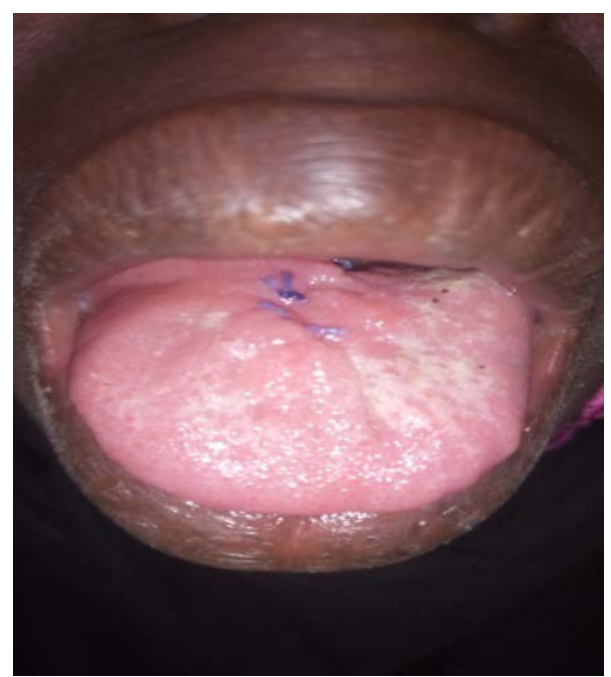

Figure 2. Excision of the lesion and stitches on the banks. 


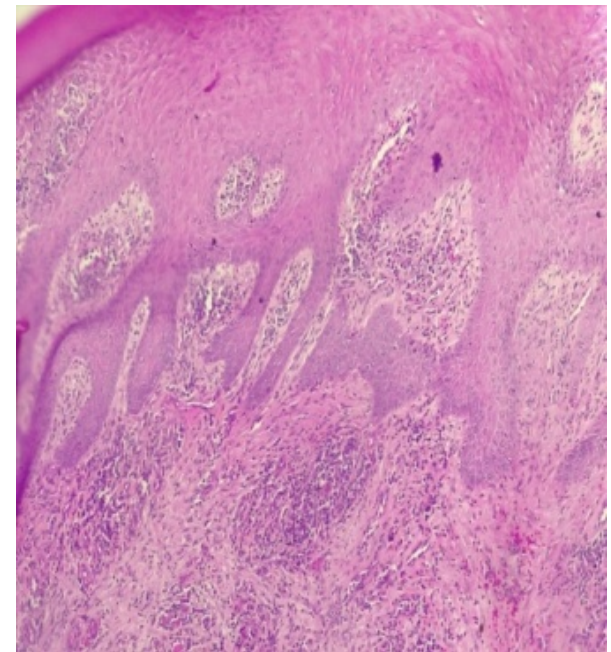

Figure 3. Histological appearance of the papilloma.

\section{Comments}

Oral papillomatosis occurs at any age, especially between 20 and 40 years old, and is found in both men and women [5].

Lingual localization is the most common but can be localized in any part of the oral cavity [5] [6].

The papilloma can be isolated as in the present observation or multiple associated with other locations. According to the literature, the papilloma is generally asymptomatic as is the case in our patient [5] [6] [7].

Human papilloma virus is implicated in the development of oral papilloma. This oral localization is mainly due to contamination by types 6 and 11 which have a low risk of malignant transformation and would be in approximately $70 \%$ responsible for the lesions. HPV at high risk of developing malignant pathology are 16 and 18 [2] [3] [5].

The coexistence of oral papilloma and HIV immunodeficiency found in our patient has been reported in the literature. People who are immunosuppressed with HIV with a CD4 count of less than $200 / \mathrm{ml}$ are more likely to be exposed to human papillomavirus infection [5].

Papilloma is a sexually transmitted infection. Transmission by contaminated objects has also been described. The mode of transmission by direct contact could be evoked in our patient before the notion of oral-genital relationships.

The oral location in the present study could be explained by sexual behavior. The site of predilection is the tongue and the palate but the lesion can occur on any surface of the oral cavity [1] [4].

Clinically, the papilloma is in the form of painless pink or whitish papules of cauliflower appearance based on implantation more often pedunculated as reported in our case [1].

The differential diagnosis is made with condyloma and warts. Warts have a predilection for the gum and the alveolar ridge, while the condylomas are larger 
than the papilloma with a wider base and appear from pink to red. . Blood tests such as the enzyme immunoassay and the polymerase chain reaction test can be performed to detect the presence of the virus [1] [6] [7]. We were unable to carry out this examination given the inadequacy of the technical platform.

The diagnosis of certainty is based on the histology which confirmed the papilloma. Surgical removal of the lesion is the treatment of choice for oral squamous papillomas, either by surgical or electrocautery excision, cryosurgery, intralesional interferon injections or laser ablation [7] [8]. In the present study, the treatment chosen was complete excision under general anesthesia. The recurrence rate is low especially in the isolated form [1] [6]. The recurrence factors are incomplete excision and HIV infection.

Although associated with HIV, we did not notice a recurrence after a 6 and 9 month follow-up.

\section{Conclusion}

Tongue papilloma is a benign proliferative lesion characterized by slow, painless growth. Its pathogenesis is linked to HPV. Early diagnosis and surgical excision should be done to avoid recurrence.

\section{Conflicts of Interest}

The authors declare no conflicts of interest regarding the publication of this paper.

\section{References}

[1] Babaji, P., Singh, V., Chaurasia, V.R., et al. (2014) Squamous Papilloma of the Hard Palate. Indian Journal of Dental Research, 5, 211-213. https://doi.org/10.4103/0975-962X.144731

[2] Palefsky, J.M. (2007) HPV Infection in Men. Disease Markers, 23, Article ID: 159137. https://doi.org/10.1155/2007/159137

[3] Sgaramella, N., Coates, P.J., Strindlund, K., et al. (2015) Expression of p16 in Squamous Cell Carcinoma of the Mobile Tongue Is Independent of HPV Infection Despite Presence of the HPV-Receptor Syndecan-1. British Journal of Cancer, 113, 321-326. https://doi.org/10.1038/bjc.2015.207

[4] Dridi, M., Ejeil, A.L., Vi-Fane, B. and Godeau, G. (2004) Oral Papilloma: A Case Report. Revue d Odonto-Stomatologie, 33, 111-117.

[5] Chaitanya, P., Martha, S., Punithvathy, R. and Reddy, M. (2018) Squamous Papilloma on Hard Palate: Case Report and Literature Review. International Journal of Clinical Pediatric Dentistry, 11, 244-246. https://doi.org/10.5005/jp-journals-10005-1519

[6] Ural, A., Arslan, S., Ersoz, S. and Deger, B. (2014) Verruca Vulgaris of the Tongue: A Case Report with a Literature Review. Bosnian Journal of Basic Medical Sciences, 14, 136-138. https://doi.org/10.17305/bjbms.2014.3.29

[7] Syrjänen, S. (2018) Oral Manifestations of Human Papillomavirus Infections. European Journal of Oral Sciences, 126, 49-66. https://doi.org/10.1111/eos.12538

[8] Percinoto, A.C., Danelon, M., Crivelini, M.M., Cunha, R.F. and Percinoto, C. (2014) Condyloma Acuminata in the Tongue and Palate of a Sexually Abused Child: A Case Report. BMC Research Notes, 7, 467. https://doi.org/10.1186/1756-0500-7-467 